\title{
Calibration of QUAL2K model in Brazilian micro watershed: effects of the land use on water quality
}

\author{
Calibração do modelo QUAL2K em uma micro bacia brasileira: \\ efeitos do uso e ocupação do solo na qualidade da água
}

Flávia Bottino $^{1}$, Ive Ciola Ferraz ${ }^{2}$, Eduardo Mario Mendiondo ${ }^{1}$ and Maria do Carmo Calijuri ${ }^{1}$

${ }^{1}$ Departamento de Hidráulica e Saneamento, Escola de Engenharia de São Carlos, Universidade de São Paulo - USP, Av. Trabalhador São-Carlense, 400,

CEP 13566-590, São Carlos, SP, Brazil

e-mail: flaviabottino@yahoo.com.br; emm@sc.usp.br; calijuri@sc.usp.br

${ }^{2}$ Departamento de Meio Ambiente - Coordenadoria de Recursos Hídricos, Av. Prof. Frederico Hermann Jr., 345, prédio 12, $3^{\circ}$ andar, CEP 05459-900, Pinheiros, São Paulo, SP, Brazil e-mail: ive@ambiente.sp.gov.br

\begin{abstract}
Aim: This study aimed to evaluate the water quality of Canha River micro watershed (Ribeira de Iguape Valley, São Paulo State, Brazil) and to calibrate the QUAL2K model with field data; Methods: Five variables of water quality were analyzed (water temperature, dissolved oxygen, $\mathrm{pH}$, electric conductivity and turbidity), as well as flow and velocity, in eight sampling stations from September, 2006 to July, 2007. It was performed a correlation test between observed data and simulated data; Results: The dissolved oxygen concentration was high (over than $5.0 \mathrm{mg} . \mathrm{L}^{-1}$ ) during sampling period. The headwater presented the lowest concentrations of this variable. The electric conductivity did not exceed $80 \mu \mathrm{S} . \mathrm{cm}^{-1}$ and the $\mathrm{pH}$ did not range (0.5-1). The hydraulic variables were in agreement with River Continuum Concept. Although correlation test was not successful for some variables, the simulated data followed observed data; Conclusions: The rainfall linked to land use was important for obtained results. The watershed characteristics, as high slope, for example, were essential mainly to dissolved oxygen concentrations. Even though QUAL2K has some limitations its use is recommended for water resources management and future purposes.
\end{abstract}

Keywords: modeling, QUAL2K, water quality, land use, brazilian watershed.

Resumo: Objetivo: $\mathrm{O}$ presente estudo teve por objetivo avaliar a qualidade da água da microbacia do rio Canha (Baixo Ribeira de Iguape, São Paulo, Brasil) e calibrar o modelo QUAL2K com os dados obtidos em campo; Métodos: Foram analisadas cinco variáveis de qualidade da água (temperatura da água, oxigênio dissolvido, $\mathrm{pH}$, condutividade elétrica e turbidez), bem como vazão e velocidade de escoamento, em oito pontos amostrais durante setembro de 2006 a julho de 2007. A comparaçáo entre os dados simulados e observados foi feita através de um teste de correlação simples; Resultados: As concentraçôes de oxigênio dissolvido foram altas (acima de 5,0 mg. $\mathrm{L}^{-1}$ ) durante todo o período de amostragem, sendo que na nascente observaram-se as menores concentraçóes. A condutividade elétrica não ultrapassou $80 \mu{\mathrm{S} . \mathrm{cm}^{-1}}^{-1}$ o $\mathrm{pH}$ teve uma pequena faixa de variação $(0,5$ a 1$)$. As variáveis hidráulicas seguiram a teoria do Continuum fluvial. Os dados simulados seguiram a mesma tendência dos dados observados, embora o teste de correlação não tenha sido satisfatório para todas as variáveis; Conclusóes: A precipitação pluviométrica aliada à modificação do tipo de uso e ocupação do solo foram os principais responsáveis pelos resultados obtidos. As características da bacia, como alta declividade, por exemplo, também foram importantes, principalmente para as concentraçôes de oxigênio. Embora o modelo QUAL2K tenha algumas limitaçóes, seu uso para gerenciamento dos recursos hídricos e propostas de cenários futuros é recomendado.

Palavras-chave: modelagem, QUAL2K, qualidade da água, uso e ocupação do solo, micro bacia brasileira. 


\section{Introduction}

The growing rate of the population has caused a remarkable increase of the demand for natural resources due to such processes as urbanization, agriculture and industrialization. The direct consequences refer to the quantity and quality of the available freshwater to human consumption. Due to problems related to water resources it is essential to improve monitoring, research and management actions in order to ensure their effective managing. (Calijuri and Bubel, 2006).

In this regard water quality models have been used as an important tool (Bongartz et al., 2007; Fang et al., 2008; He et al., 2008; Sardinha et al., 2008). These models are able to predict water quality variations in a long and short term linking them to hydrology, river hydraulic and land use. Furthermore some human activities can damage aquatic life and therefore harm the ecosystem balance. This way models can characterize alternatives to support the evaluation of different results. Despite the importance of mathematical modeling on water quality researches it is essential that the model be critically chosen. There are a lot of models available but the most appropriate is the one that meets the research objectives.

The QUAL2K model is the new version of the widely used QUAL2E. QUAL2K is distributed by USEPA (United States Environmental Protection Agency, 2007) and it is based on differential equations for one-dimensional systems and steady state flow. This model is efficient to simulate water quality and hydrological conditions of streams as well as systems with diffusive pollution loads. Park and Lee developed QUAL2K in order to correct the QUAL2E limitations. Therefore QUAL2K has many new elements; it is useful in data limited conditions, is freely available and are not reserved for large rivers (i.e. deep and wide).

Some researches used QUAL2K to simulate water quality (Park and Lee, 2002; Kannel et al., 2007) but in Brazil these studies are unusual. The present research aimed the evaluation of the water quality of a micro watershed used to public supply that is undergoing modifications of land use. Moreover the calibration of QUAL2K model was performed with the Canha River data.

\section{Material and Methods}

\subsection{Study area}

The micro watershed of the Canha River is into the Ribeira de Iguape Watershed that is located in the south of São Paulo State. This watershed preserves a great part of the remnant area of the Atlantic forest. It is under continuous process of degradation due to the accelerated urban growth, deforestation and industrial activities (Calijuri et al., 2003).

The Canha River is around $27.5 \mathrm{~km}$ long and it flows through regions of dense forest and banana plantations. It crosses Jacupiranga's rural zone and flows into Jacupiranga River next to the Sewage Treatment Plant (latitude: 24 41' 18"; longitude: $\left.47^{\circ} 59^{\prime} 44^{\prime \prime}\right)$.

The average altitude of the Canha River does not exceed $200 \mathrm{~m}$. The topography is slightly restricted. As for geology there are predominant Plains and Wave-Cut Terraces. On pedology there is predominance of Haplic Cambissol (Calijuri et al., 2003). According to Calijuri et al. (2007), the soils of the region are considered with a high susceptibility to erosion. The Canha River is used to public supply, which increase the importance of determining both the water quality and the characterization of the micro watershed as one.

\subsection{Samplings}

Samplings were carried out in different periods (September 2006, January, April and July 2007) in eight sampling stations along the longitudinal axle of the Canha River (Figure 1). The flow and velocity measures were performed according to Righetto (1998). For determinations of the water temperature, electric conductivity, $\mathrm{pH}$ and turbidity, a multiparametric probe and turbidimeter were used. Dissolved oxygen (DO) was measured according APHA (1999).

The samples were collected in water sub-surface $(10 \mathrm{~cm}$ under the water level). All the sampling stations presented mean depth lower than $1 \mathrm{~m}$, including the period of higher rainfall.

The model used in the study was QUAL2K, made available by the USEPA, which was calibrated with the field data of the Canha River, such as flow, slope, bottom width, water height, sampling station distance and water quality variables (water temperature, electric conductivity, $\mathrm{pH}$, solids, $\mathrm{DO}$ and nutrients). According to QUAL2K manual (Chapra and Pelletier, 2006) the parameters (reaeration coefficient, settling coefficients, DO consumption, production, etc) were insert in the spreadsheet of model to fit the calibration.

The river was segmented according to the land use. The Table 1 presents this division as well as the local characteristics. The division of elements 

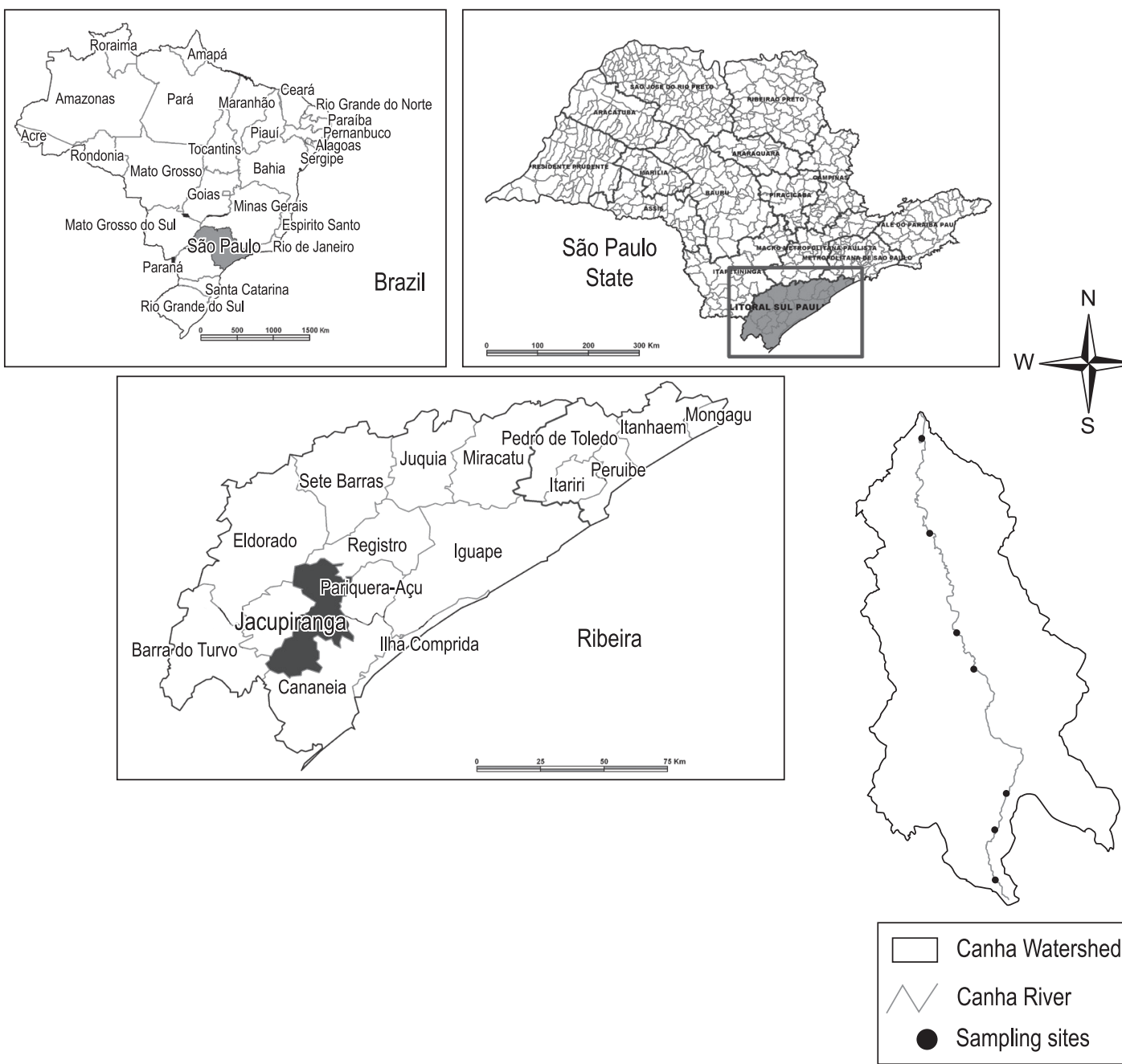

Figure 1. Schematic map showing Ribeira de Iguape Watershed, São Paulo State, Brazil, and Canha River Watershed with sampling stations. Fonte: IBGE (2000).

Table 1. Representation of the simulated segments.

\begin{tabular}{lccc}
\hline \multicolumn{1}{c}{ Segment } & End segment & Distance $(\mathrm{km})$ & Characteristics \\
\hline Headwater & Rural area & 3 & Riparian forest/livestock \\
Rural property & Raposo farm & 6 & Livestock/banana crop \\
Raposo farmer & SP 222 Road & 15.2 & Banana crop/urban Area \\
\hline
\end{tabular}

was made based on the distance between sampling stations and is represented in the Table 2.

The hydraulic variables calibration was performed according the following procedures:

i) Flow: it was used the mean flow and the difference between downstream flow and upstream flow was considered as a diffuse source.

According to QUAL2K model a steady-state flow is implemented for each model element as (Equation 1):
$\mathrm{Q}_{\mathrm{i}}=\mathrm{Q}_{\mathrm{i}-1}+\mathrm{Q}_{\mathrm{in}, \mathrm{i}}-\mathrm{Q}_{\text {out }, \mathrm{i}}$

where: $\mathrm{Q}_{\mathrm{i}}=$ outflow from element $i$ into the downstream element $\mathrm{i}+1\left(\mathrm{~m}^{3} \mathrm{~d}^{-1}\right)$;

$\mathrm{Q}_{\mathrm{i}-1}=$ inflow from the upstream element $\mathrm{i}-1$ $\left(\mathrm{m}^{3} \mathrm{~d}^{-1}\right)$;

$\mathrm{Q}_{\mathrm{in}-1}=$ total inflow into the element from point and nonpoint sources $\left(\mathrm{m}^{3} \mathrm{~d}^{-1}\right)$;

$\mathrm{Q}_{\text {out } \mathrm{i}}=$ total outflow from the element due to point and nonpoint withdrawals $\left(\mathrm{m}^{3} \mathrm{~d}^{-1}\right)$.

ii) To water velocity: the model calculates the depth and the velocity in one of three ways: 
Table 2. Representation of simulated elements.

\begin{tabular}{cc}
\hline Elements & Reach $(\mathrm{km})$ \\
\hline 1 & 3 \\
2 & 2 \\
3 & 6 \\
4 & 2.9 \\
5 & 6 \\
6 & 5.4 \\
7 & 0.9 \\
\hline
\end{tabular}

weirs, rating curves, and Manning equations. This study was performed using Manning equation.

The mean velocity of each element was used in the model and its calibration was carried out according to the watershed slope and $\mathrm{n}$ of Manning for natural channels. Under conditions of steady flow the Manning equation can be used to express the relationship between flow and depth (Equation 2):

$\mathrm{Q}=\frac{\mathrm{S}_{0}{ }^{1 / 2}}{\mathrm{n}} \frac{\mathrm{Ac}^{5 / 3}}{\mathrm{P}^{2 / 3}}$

where: $\mathrm{Q}=$ flow $\left(\mathrm{m}^{3} \mathrm{~s}^{-1}\right)$;

$\mathrm{S}_{0}=$ bottom slope $(\mathrm{m} / \mathrm{m})$;

$\mathrm{n}=$ Manning roughness coefficient;

$A_{c}=$ cross sectional area $\left(\mathrm{m}^{2}\right)$;

$\mathrm{P}=$ wetted perimeter $(\mathrm{m})$.

The model also provides a list of Manning roughness coefficient. This list as well as the classification of Rosgen (Rosgen and Silvey, 1996) were used in this study.

iii) The water quality variables were calibrated using data of the different samplings and the difference between downstream data and upstream data was considered as diffuse source.

The temperature model takes into account heat transfer from adjacent elements, loads, withdrawals, the atmosphere and the sediment. A heat balance can be written for an element as (Equation 3):

$$
\begin{aligned}
& \frac{d T}{d t}=\frac{Q_{i-1}}{V_{i}} T_{i-1}-\frac{Q_{i}}{V_{i}} T_{i}-\frac{Q_{\text {out }, i}}{V_{i}} T_{i}+\frac{E_{i}^{\prime}-1}{V_{i}}\left(T_{i-1}-T_{i}\right) \\
& +\frac{E_{i}^{\prime}}{V_{i}}\left(T_{i+1}-T_{i}\right)+\frac{W_{h, i}}{\rho_{w} C_{p w} V_{i}}\left(\frac{m^{3}}{10^{6} m^{3}}\right) \\
& +\frac{J_{a i}}{\rho_{w} C_{p w} H_{i}}\left(\frac{m}{100 \mathrm{~cm}}\right)+\frac{J_{s i}}{\rho_{w} C_{p w} H_{i}}\left(\frac{m}{100 c m}\right)
\end{aligned}
$$

where: $\mathrm{T}=$ temperature in element $\mathrm{i}\left({ }^{\circ} \mathrm{C}\right)$;

$\mathrm{t}=$ time $(\mathrm{d})$;

$E^{\prime} \mathrm{i}=$ bulk dispersion between elements $\mathrm{i}$ and $\mathrm{i}+1\left(\mathrm{~m}^{3} \mathrm{~d}^{-1}\right)$;

$\mathrm{W}_{\mathrm{h}, \mathrm{i}}=$ net heat load from non point sources into element i $\left(\right.$ cald $\left.^{-1}\right)$; $\rho_{\mathrm{w}}=$ the density of water $\left(\mathrm{g} \mathrm{cm}^{-3}\right)$;

$\mathrm{C}_{\mathrm{pw}}^{\mathrm{w}}=$ the specific heat of water $\left[\mathrm{cal}\left(\mathrm{g}^{\circ} \mathrm{C}\right)^{-1}\right]$;

$\mathrm{J}_{\mathrm{a}, \mathrm{i}}^{\mathrm{pw}}=$ the air-water heat flux [cal. $\left.\left(\mathrm{cm}^{-2} \mathrm{~d}^{-1}\right)\right]$;

$\mathrm{J}_{\mathrm{s}, \mathrm{i}}=$ the sediment-water heat flux $\left[\mathrm{cal} .\left(\mathrm{cm}^{-2} \mathrm{~d}^{-1}\right)\right]$.

According to QUAL2K manual (Chapra and Pelletier, 2006), the $\mathrm{pH}$ of river is computed based on equilibrium of carbon and alkalinity. The conductivity is related to inorganic suspended solids.

In regard of the dissolved oxygen, it can increase due to plant photosynthesis and lost via Carbonaceous Biochemical Oxygen Demand (CBOD) oxidation, nitrification and plant respiration. Depending on whether the water is undersaturated or oversaturated the DO is gained or lost via reaeration. The program calculates the DO according to Equation 4 below:

So $=$ roaPhytoPhoto + roaBotA lg Photo - rocFastOxid

-ronNH4Nitr - roaPhyto Resp - roaPhyto Resp

-roaBotA lg Resp + Ox Re aer

where: roaPhytoPhoto = phytoplankton oxygen produced $\left(\mathrm{g} \mathrm{O}_{2} \mathrm{~d}^{-1}\right)$;

roaBotAlhPhoto = bottom phytoplankton oxygen produced $\left(\mathrm{g} \mathrm{O}_{2} \mathrm{~d}^{-1}\right)$;

rocFastOxid $=\mathrm{O}_{2}$ required for carbon decay $\left(\mathrm{gO}_{2} \mathrm{gC}^{-1}\right)$;

ronNH 4 Nitr $=\mathrm{O}_{2}$ required for $\mathrm{NH} 4$ nitrification $\left(\mathrm{gO}_{2} \mathrm{gN}^{-1}\right)$;

roaPhytoResp = phytoplankton oxygen consumption $\left(\mathrm{dO}_{2} \mathrm{~d}^{-1}\right)$;

roaPhytoResp = phytoplankton oxygen consumption $\left(\mathrm{gO}_{2} \mathrm{~d}^{-1}\right)$;

rodBotAlgResp = bottom phytoplankton oxygen consumption $\left(\mathrm{gO}_{2} \mathrm{~d}^{-1}\right)$.

The indexes (roa, rod, roc, and ron) are parameters and the values used were suggested by Chapra and Pelletier (2006) (Equation 5).

Ox Re aer $=k_{\mathrm{a}}(\mathrm{T})\left(\mathrm{o}_{\mathrm{s}}(\mathrm{T}\right.$, elev $\left.)-\mathrm{o}\right)$

where: $\mathrm{k}_{\mathrm{a}}(\mathrm{T})=$ the temperature-dependent oxygen reaeration coefficient $\left(\mathrm{d}^{-1}\right)$;

$\mathrm{o}_{\mathrm{s}}(\mathrm{T}$, elev $)=$ the saturation concentration of oxygen $\left(\mathrm{mg} \mathrm{O}_{2}{ }^{-1}\right)$ at temperature, $\mathrm{T}$, and elevation above sea level, elev.

iv) The parameters required by the model (see spreadsheet "Rates" of the model) were fit according values recommended by manual of model (Chapra and Pelletier, 2006) suggestions were employed to calibration. These data are widely used on literature and can to be found in the manual of the model.

The output data of model are graphics of the limnological variable (concentration) versus distance. However in this research these graphics 
were remade (concentration versus channel length [\%]), in order to favor understanding and discussion of results. For flow data the graphics showed the flow (L.s $\left.{ }^{-1}\right)$ versus channel length (\%) and in the secondary axis was used specific flow $\left(\mathrm{L} \cdot \mathrm{s}^{-1} \mathrm{~km}^{-2}\right)$.

The relationship between field measurements and simulated values was performed using a correlation test.

\section{Results}

In Brazil, especially in São Paulo State, the rainy season is from October to March. However, 2007 was an atypical year with intense precipitation in July (67 $\mathrm{mm}$ seven days before the sampling). Higher flows were observed in July - from 19 L. $s^{-1}$ (headwater) to $4619 \mathrm{~L} . \mathrm{s}^{-1}$ (mouth) and lower flows were recorded on September (spring) - from $14 \mathrm{~L} \cdot \mathrm{s}^{-1}$ (headwater) to $595 \mathrm{~L} . \mathrm{s}^{-1}$ (mouth). Considering the specific loads, the higher values were obtained in headwater and lower in the mouth during all seasons (Figure 2).

The flow calibration in the QUAL2K model was successful and the correlation test between observed data and simulated data showed mean $\mathrm{R}^{2}=0.99$.

There was a wide variation of velocity (Figure 3 ), mainly in river medium course, which is inside of rural properties. The spatial variation was higher in the spring and lower in the summer, with values ranging from 0.11 to $0.73 \mathrm{~m} / \mathrm{s}$ and 0.16 to $0.39 \mathrm{~m} / \mathrm{s}$, respectively. The highest velocity values were obtained in the winter and the lowest ones in the autumn. In relation to simulation the correlation was successful $\left(R^{2}=0.95\right)$

As expected, the lowest water temperatures were recorded in the winter and autumn and the highest ones in the summer and in the spring (Figure 4). Considering the correlation test, it was possible observe in winter $\mathrm{R}^{2}<0.7$ and for the other seasons the mean value was 0.9 .

Regarding DO, the lowest concentrations occurred in the headwater, with increases at the medium river course. During the summer, autumn and winter periods were observed a slight decrease of DO in the sampling station 5 (medium river course). Decrease of values was also found in samplings stations near to the river mouth in all seasons The highest DO concentrations were recorded during the winter, and the sampling station 4 (medium river course) presented the highest value of all sites $\left(9.1 \mathrm{mg} . \mathrm{L}^{-1}\right)$. The lowest DO concentrations occurred during the summer (headwater: $5.93 \mathrm{mg} . \mathrm{L}^{-1}$ ), followed by autumn and spring (Figure 5). Although correlation test was not successful $\left(\mathrm{R}^{2}=0.98\right.$ in spring and $\mathrm{R}^{2}<0.7$ for all seasons) the simulated data followed the observed data.

The electric conductivity increased from upstream to downstream in all seasons (Figure 6). The values observed in the spring and in the summer were quit similar. On the other hand, higher longitudinal variation and lower conductivity values were found during the winter sampling. Correlation test presented $R^{2}<0.7$ for spring and autumn, in the summer $\mathrm{R}^{2}$ was 0.9 and in the winter the value was 0.8 .

The $\mathrm{pH}$ values did not presented longitudinal variation however temporal variation was observed (Figure 7). During the period of higher rainfall (July) there was a small decrease of $\mathrm{pH}$ with values between 5.82 (sampling station 8) and 6.06 (sampling station 3). In this research, this variable had low variation $(0.5-1)$. For $\mathrm{pH}$ the correlation analysis was unsuccessful because $\mathrm{R}^{2}$ value was $<0.7$ for most of periods. Just in the spring the $\mathrm{R}^{2}$ was 0.7 .

In all samplings, except in July (winter), the turbidity values decreased from the headwater to the mouth. The lowest value was recorded in September (spring) sampling (Figure 8) and the highest during in July. It's important to mention that turbidity is not an input and output data for the QUAL2K model simulation. Therefore, the present study does not show the simulated data for this variable.

\section{Discussion}

Canha River flow and velocity dynamics followed the River Conitnuum Concept (Vannote et al., 1980). During all seasons these variables presented temporal patterns, with contribution of drainage dynamic, mainly due to the high slope near to the headwater. In addition, the absence of point source of pollution along the river suggested a continuity of the flow and the velocity.

The QUAL2K model does not use the rainfall as an input data, however the hydraulic variables have great correlation with hydrologic data. This way the calibration of flow and velocity may be used to analyze rainfall patterns. Moreover, the calibration way of these variables was successful.

Galbraith and Burns (2007) reported that the watershed size, its slope, as well as the hydrology and land use have an important role in the water quality. Thus, it means that the water quality variables of the Canha River are strongly related to land use of its catchment. The sampling stations located in the highlands are surrounded by vegetation (about 90\% of forest), reflecting differences in water physical 

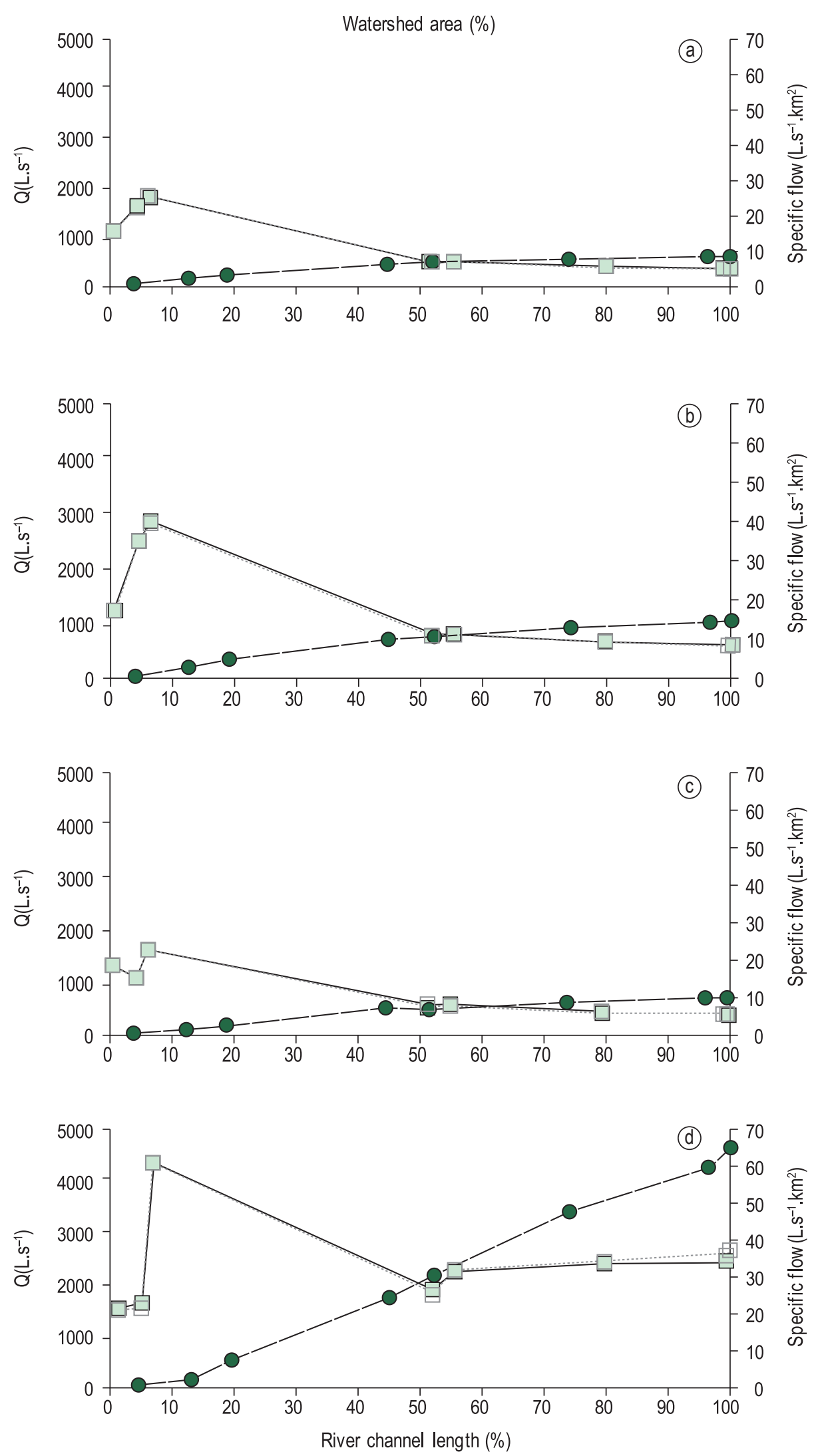

Figure 2. Flow variation in Canha River (inferior abscissa, left ordinate) and specific flow variation in the watershed increment (superior abscissa, right ordinate), during the spring (a - September), summer (b - January), autumn (c - April) and winter ( $\mathrm{d}$ - July) periods, respectively. O: observed flow; $\square$ : observed specific flow; $\square$ : simulated specific flow. 

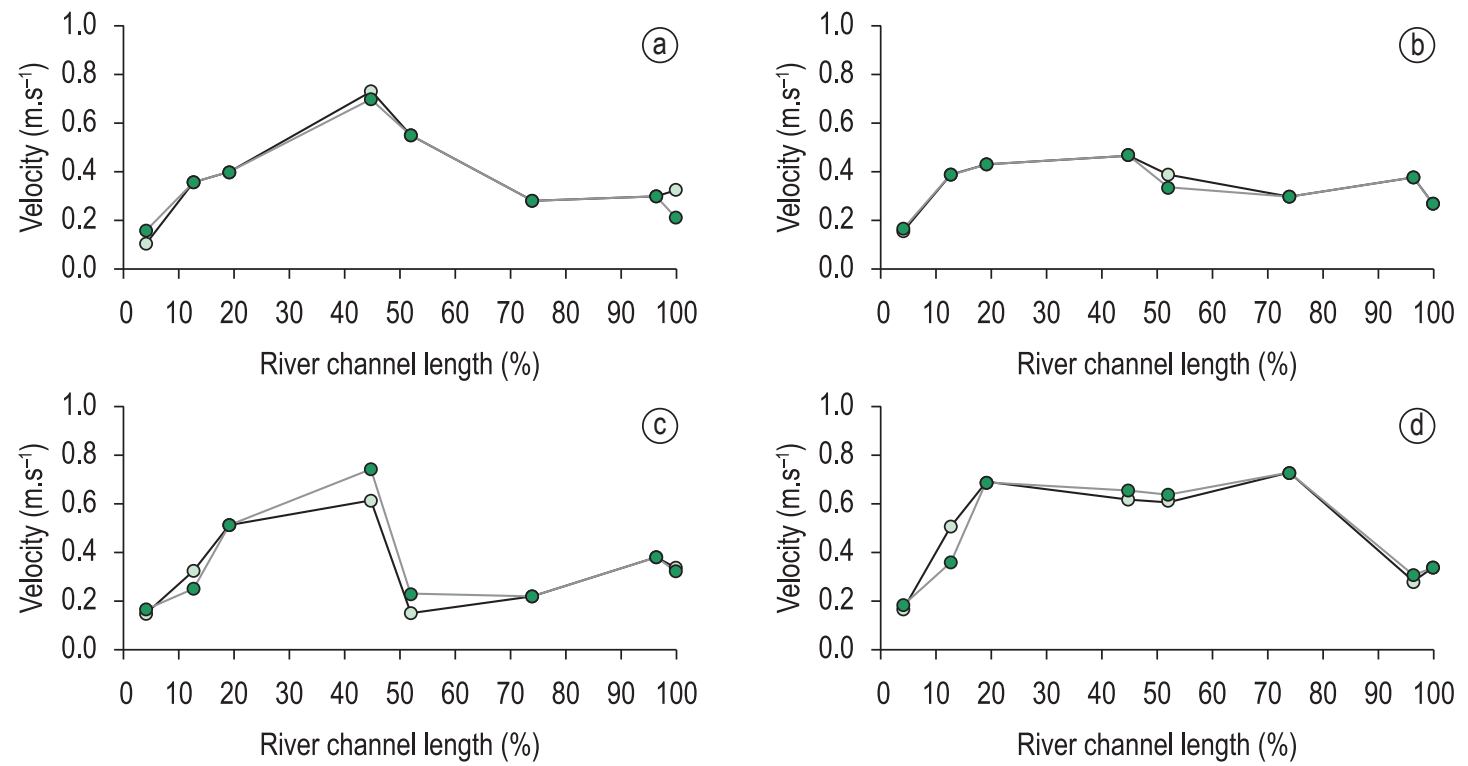

Figure 3. Velocity variation $(\mathrm{m} / \mathrm{s})$ in Canha River, during the spring (a - September), summer (b - January), autumn (c - April) and winter (d - July) periods, respectively. O: observed velocity; "O": simulated velocity.
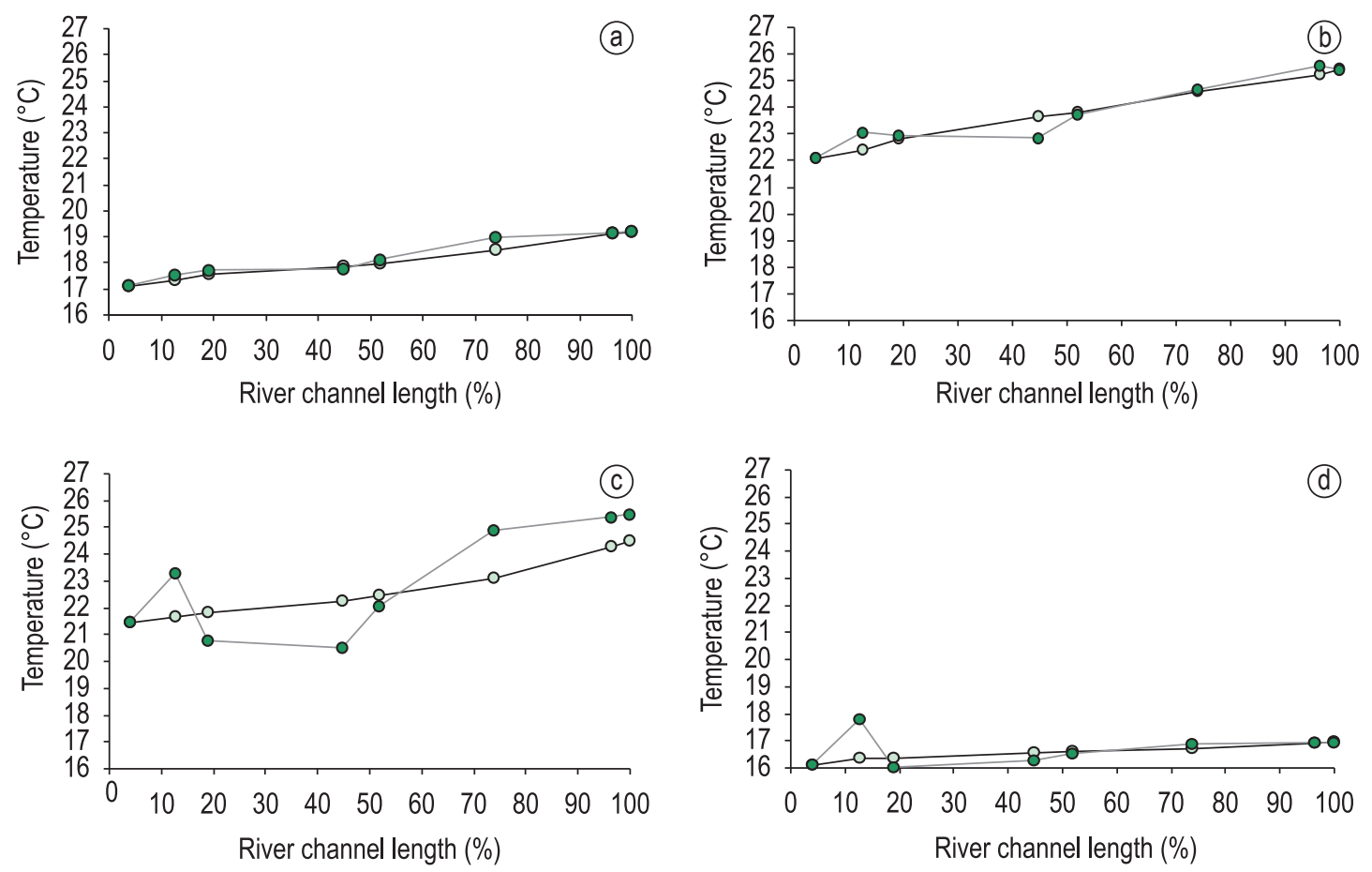

Figure 4. Water temperature variation $\left({ }^{\circ} \mathrm{C}\right)$ in Canha River, during the spring (a - September), summer (b - January), autumn (c - April) and winter ( $\mathrm{d}$ - July) periods, respectively. O: observed water temperature; "O": simulated water temperature.

and chemical variables. However, in lowlands and in the medium river course the vegetation was partially or totally removed (about 15\% of areas with agriculture and $40 \%$ of urban area). As a result, changes were observed in the values of limnological and hydrological variables.
The water temperature of the Canha River is in agreement with the theory proposed by Vannote et al. (1980) too. As expected, lower temperatures were observed in areas with remaining riparian forest. Rivers surrounded by forest have lower water temperature due to shadow. Moreover, smaller rivers are susceptible to the largest 

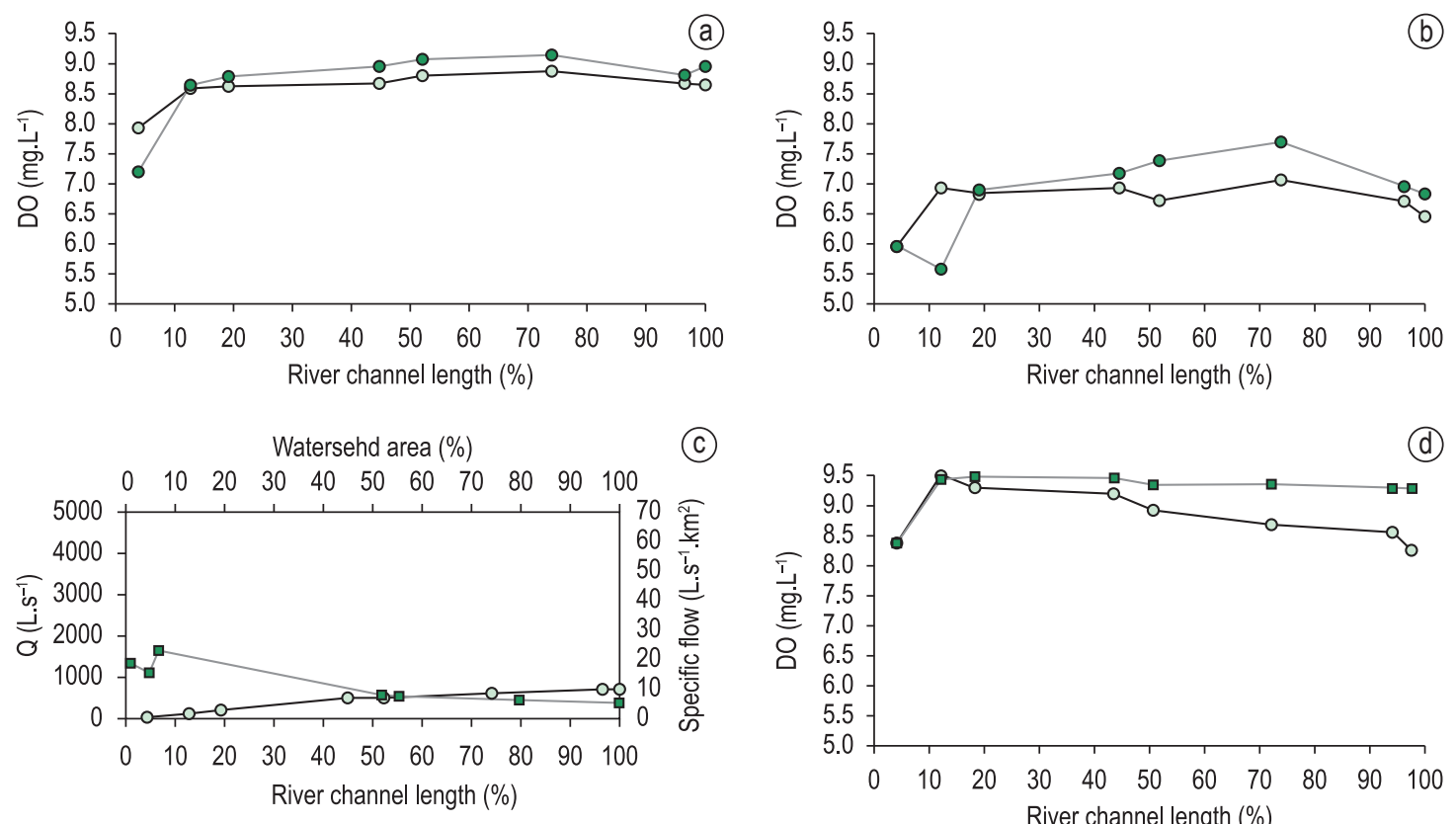

(C)

(d)

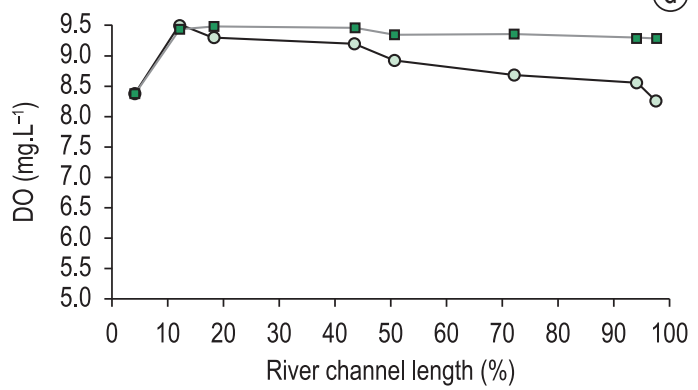

Figure 5. Concentrations of dissolved oxygen $\left(\mathrm{mg} \cdot \mathrm{L}^{-1}\right)$ in Canha River, during the spring (a - September), summer (b - January), autumn (c - April) and winter (d - July) periods, respectively. O: observed dissolved oxygen; “ $\square$ ": simulated dissolved oxygen.
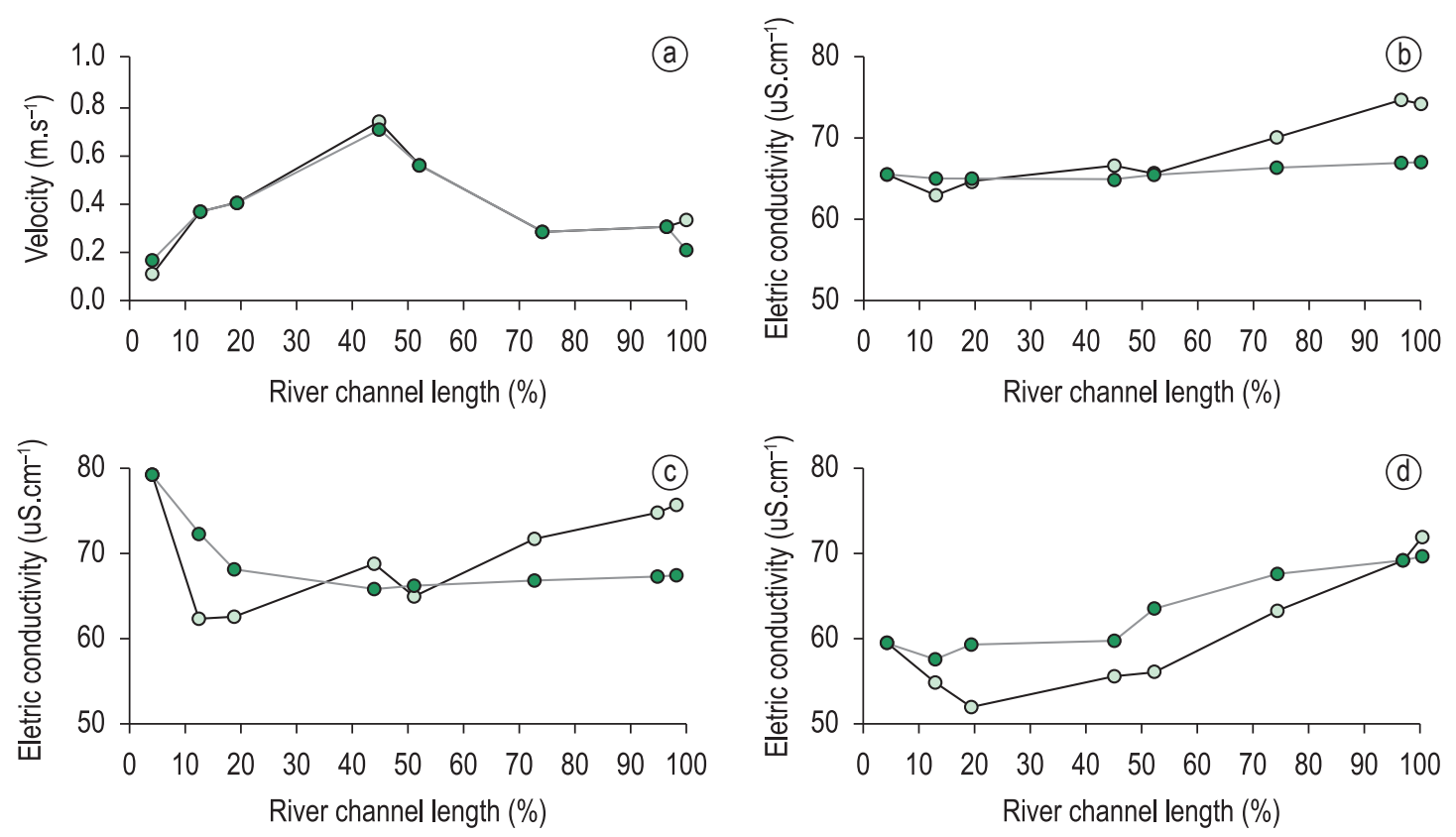

Figure 6. Electric conductivity variation $\left(\mu \mathrm{S} . \mathrm{cm}^{-1}\right)$ in Canha River, during the spring (a - September), summer (b - January), autumn (c - April) and winter (d - July) periods, respectively. O: observed electric conductivity; "O": simulated electric conductivity.

temperature variation (Vannote et al., 1980). Canha River is a micro watershed and its tributaries are until third order, therefore the water temperature may be influenced by watershed characteristics.

According to Wetzel (1983) the oxygen solubility in aquatic systems is related to temperature. This fact was observed in the Canha River with higher concentration recorded in July. Canha River presented DO concentrations over than $5.0 \mathrm{mg} . \mathrm{L}^{-1}$ during all studied period. These high concentrations should be related to high slope and water velocity.

However, it was important to note that during all seasons, the sampling station 1 presented low concentrations of DO. In autumn were recorded the 

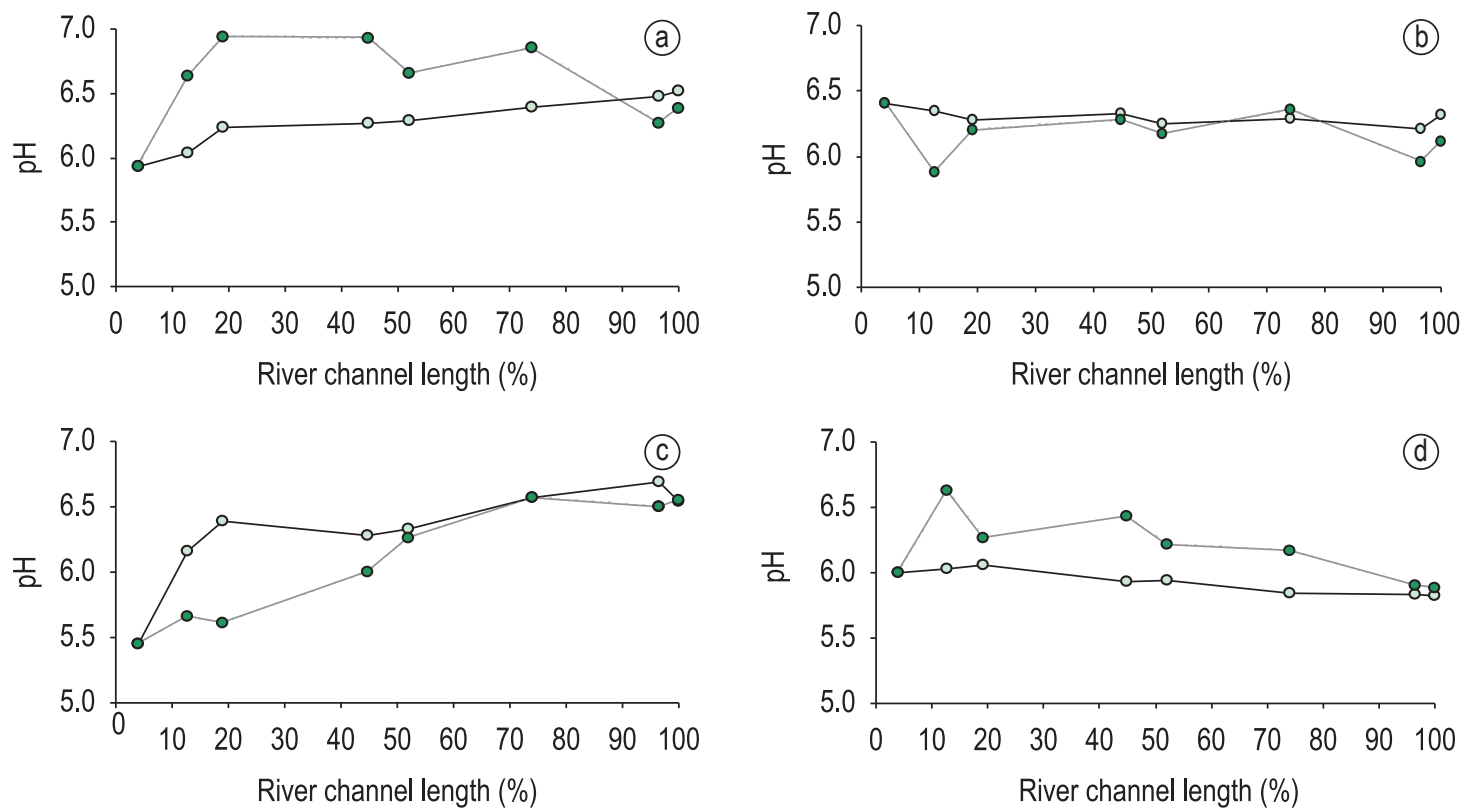

Figure 7. $\mathrm{pH}$ variation in Canha River, during the spring ( $\mathrm{a}$ - September), summer (b - January), autumn (c - April) and winter (d - July) periods periods, respectively. O: observed $\mathrm{pH}$; “o": simulated $\mathrm{pH}$.
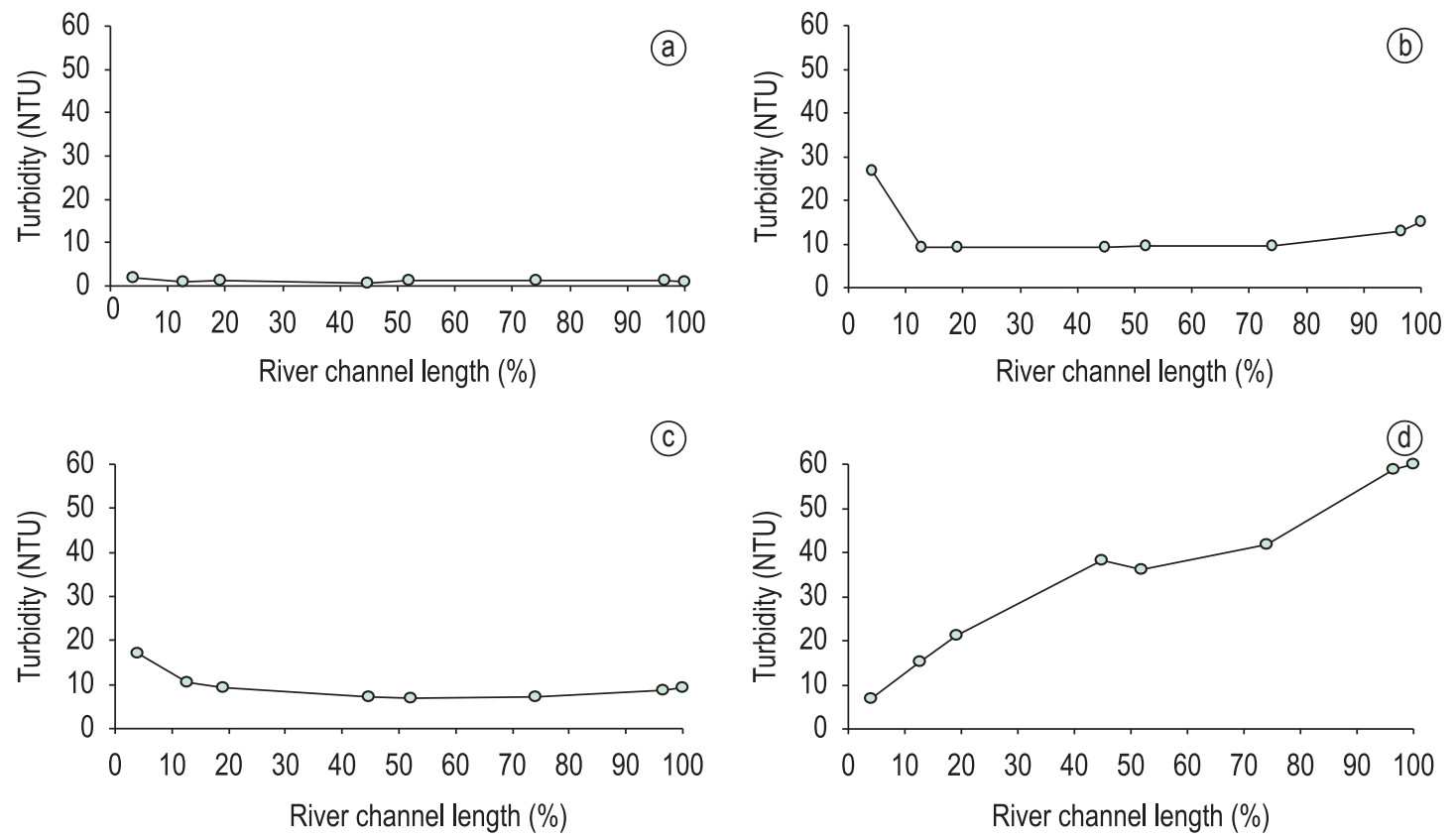

Figure 8. Turbidity variation (NTU) in Canha River, during the spring (a - September), summer (b - January), autumn (c - April) and winter ( $\mathrm{d}$ - July) periods, respectively. O: observed turbidity.

lowest concentration in headwater $\left(5.9 \mathrm{mg} . \mathrm{L}^{-1}\right)$. This result may have occurred due to organic matter from the riparian forest. The influence of organic matter on this variable was observed by Sardinha et al. (2008) that reported reduced DO concentration in Meio stream (Leme city, São Paulo State, Brazil) with effluent discharge input.
Although the DO concentration was low in headwater of Canha River, this values are high (mean of $7.0 \mathrm{mg} . \mathrm{L}^{-1}$ ) when compared with Cintra River in Brazil (4.4 mg. $\mathrm{L}^{-1}$ ) (Belluta et al., 2009) and Meio stream (1.5 mg.L-1).

According to Groppo et al. (2008) the major contribution for oxygen depletion is urban growth. 
The urbanization removes the riparian forest besides it contributes to input of the sewage and industrial effluent. In despite of absence of riparian vegetation along the Canha River, the oxygen concentrations were high in all sampling stations. The decreases were higher in medium river course during summer and autumn.

The equations showed in the manual of QUAL2K model show oxygen consumption by $\mathrm{BOD}$, but in the equation of dissolved oxygen balance this consumption is not showed. However is not possible to know if this is an error in the manual or if the balance of dissolved oxygen has a failure.

Sardinha et al. (2008) used QUAL2K model to simulate the DO in Meio stream. The authors concluded that the model was consistent since the observed data were fitted with the simulated data. Similar results were obtained to Canha River.

The electric conductivity provides information about the metabolism of the aquatic ecosystem, showing the relation among waters, watershed geological formation and allochthonous material input. Donohue et al. (2006) studying the relation among chemical variables of rivers in Ireland and the ecological status of its watershed noted that the electric conductivity acts as an important indicator of watershed land use.

The longitudinal variation of the electric conductivity occurred from upstream to downstream in the Canha River. In all sampling period the highest conductivity was recorded in river mouth except in autumn. This result may be related to the low rainfall in this season. Higher electric conductivity was also found in Cintra River (Brazil) during dry season (Belluta et al., 2009). In addition the high conductivity values in river mouth (near urbanization) may be associated with input of material as clandestine sewage and litter.

Marques et al. (2007) suggested that in dry period there are low concentrations of dissolved compounds in water due to absence of runoff. As a result the water quality can be better, although in the rainy season the dilution effect improves the river conditions. Canha River presented lowest electric conductivity during rainy season, probably due to ionic dilution. Regarding the QUAL2K model, there is no mention to the calculation of the electric conductivity, however it is related to the suspended inorganic solids.

The headwater of the Canha River presented the lowest $\mathrm{pH}$ and the values were similar in all samplings (between 5.0 and 6.5). The decomposition processes of vegetation in headwater may be decreased the
$\mathrm{pH}$ values. Similar patterns were found in Córrego Rico Watershed (Taquaritinga country, São Paulo State, Brazil) that showed lowest $\mathrm{pH}$ in preserved headwater (Donadio et al., 2005). The temporal variation was in agreement with study developed in Ribeira de Iguape watershed with low $\mathrm{pH}$ values in rainy period (Marques et al., 2007).

It is important to highlight that the $\mathrm{pH}$ calibration in the QUAL2K model has indirect relation with phytoplankton respiration; however, no data referent to the algae were calibrated at the present research, which may cause difference between simulated and observed values of $\mathrm{pH}$.

During the winter it was registered maximum value of turbidity (60 NTU) next to the river mouth. This fact may be related to the high rainfall that occurred in this period and promoted the allochthonous material input and resuspension of sediment. The results obtained for Ribeira de Iguape watershed were similar (Marques et al., 2007) with highest values observed during rainy season. Oliveira et al. (2008) found 60 NTU in headwater of the Modeneis Stream (Limeira country, São Paulo State, Brazil) and concluded that absence of riparian forest was essential for this result.

The input of allochotonous material and resuspension of sediment may improve the longitudinal variation of the turbidity in the drier periods. Roy et al. (2003) analyzing environmental answers due to the different types of land use in the watershed of the Etowah River, Georgia, verified that the turbidity was related to the increase of the urban and agricultural areas and decrease of the forest coverage. In the Canha River, despite of urban e agriculture development in their margins, the diffuse sources input seems does not influence the turbidity values yet.

The QUAL2K model has some structural and functional limitations such as performing simulations in a non-permanent way and the impossibility of to change the internal structure of the model, i.e., insert equations that better represent the reality (Gonçalves, 2009). Despite this information, the model has been widely used for water quality assessment. In this research QUAL2K showed some limitations, but the simulated data followed the observed data (although it was observed $\mathrm{R}^{2}<0.7$ for some variables).

The correlation test was successful for hydraulic data, but some model input data (algae respiration, algae death or sediment demand) do not allow a suitable relationship for limnological data such as oxygen and $\mathrm{pH}$. 
The graphs showed in this study (\% of length or $\%$ of watershed area) allow comparison between different researches in ecosystems with different sizes. Furthermore it provides more effective decision for each watershed segment with dissimilar land use and the loads linking quantitative and qualitative aspects, an efficient approach for water resources management.

\section{Conclusion}

The aim of this study was to evaluate the water quality of the Canha River micro watershed based on the water physical and chemical variables analysis and in its land use. QUAL2K model was employed for calibration field data. This model is used for small rivers with steady state flow conditions. The riparian forest in the headwater was the main factor that caused differentiations in the values found for the physical and chemical variables, as well as, its removal to include the banana culture and the proximity with the urban area of Jacupiranga influenced the values found in the medium river course and downstream. In these sampling stations DO concentrations decreased and electric conductivity increased. There was not important $\mathrm{pH}$ variation along the river and turbidity presented longitudinal variation from headwater to river mouth in all seasons. The electric conductivity and turbidity was related to low rainfall and $\mathrm{pH}$ values with high rainfall.

Flow and velocity were related to rainfall and it is in agreement with the River Continuum Concept proposed by Vannote et al. (1980). The concentrations of dissolved oxygen were elevated during all study, due to high slope and absence of point pollution sources.

Overall, it's possible to conclude, from field data, that the Canha River is not polluted but the constant change in land use may harm the water quality. For this reason it is necessary to re-evaluate the status of this river according to the Brazilian legislation.

The QUAL2K model provided a satisfactory result to the calibration with the sampling data of the Canha River. Nevertheless many parameters and applications presented in the model are assigned to tempered environments, which may compromise the calibration of some variables. Moreover some considerations in manual program are not suitable. However, the QUAL2K model is recommended for water quality simulation in order to maintain an effective management of the water resources and propose future scenarios.

\section{References}

American Public Heath Association - APHA. Standard methods of the examination of water and wastewater. 1999. 20th ed. Washington: APHA.

BELlUTA, I., SILVA, AMM., CAMARGO, CHC. and RALL, VLM. 2009. Impacts on the springs of Cintra Stream (Botucatu, São Paulo State, Brazil) and downstream variation in water quality. Acta Limnologica Brasiliensia, vol. 21, no. 1, p. 11-24.

BONGARTZ, K., TIMOTHY, DS., BABOROWSKI, M. and LINDENSHMIDT, KE. 2007. Monitoring, assessment and modeling using water quality data in Saale River Basin, Germany. Environmental Monitoring Assessment, no. 135, p. 227-240.

CALIJURI, ML., LOURES, SSP., SANTIAGO, AF., SCHAEFER, CEGR., LUGĀO, WG. and ALVES, JEM. 2007. Identificação de áreas alternativas para disposição de resíduos sólidos na região do Baixo Ribeira de Iguape, SP. Engenharia Sanitária e Ambiental, vol. 12, no. 3, p. 335-342.

CALIJURI, MC. and BUBEL, APM. 2006. Conceituação de microbacias. In: LIMA, WP. and ZAKIA, MJB., eds. As Florestas Plantadas e a Água. São Carlos: Rima Editora. p. 45-60.

CALIJURI, MC., MENDIONDO, EM., VARESCHE, MBA., VAZOLLER, RF., DOMINGOS, MD, DOS SANTOS, ACA. and CALIJURI, ML. 2003. Estudos dos sistemas naturais e artificiais redutores de cargas poluidoras para a sustentabilidade dos recursos hidricos do Baixo Ribeira de Iguape, SP. Projeto temático FAPESP.

CHAPRA, SC. and PELLETIER, GJ. 2006. QUAL2K A modelling framework for simulating river and stream water quality. Medford: Documentation and users manual Civil and Environmental Engineering Dept Tufts University.

DONADIO, NMM., GALBIATTI, JA. and PAULA, RC. 2005. Qualidade da água de nascentes com diferentes usos do solo na bacia hidrográfica do Córrego Rico, São Paulo, Brasil. Engenharia Agrícola, vol. 25, no. 1, p. 115-125.

DONOHUE, .I, GARRILÉ, ML. and MILLS, P. 2006. Linking catchment characteristics and water chemistry with ecological status of Irish rivers. Water Research, vol. 40, p. 91-98. http://dx.doi. org/10.1016/j.watres.2005.10.027

FANG, X., ZHANG, J., CHEN, Y. and XU, X. 2008. QUAL2K model used in water quality assessment of Qiantang River, China. Water Environmental Research, vol. 80, no. 1, p. 2125-2133. http://dx.doi. org/10.2175/106143008X304794

GALBRAITH, LM.and BURNS, CW. 2007. Linking land-use, water body type and water quality in Southern New Zealand. Landscape Ecology, no. 22, p. 23-241. 
GONÇALVES, JCS. 2009. Desenvolvimento de modelo numérico para simulação da qualidade da água em rios utilizando o software Vensim PLE ${ }^{\circledR}$. Sáo Paulo: Universidade de Sáo Paulo. [Master Thesis in Hydraulic Engineering and Sanitation].

GROPPO, JD., MORAES, JM., BEDUSCHI, CE., GENOVEZ, AM. and MARTINELLI, LA. 2008. Trend analysis of water quality in some rivers with different degrees of development within the São Paulo State, Brazil. River Research and Appllications, vol. 24, p. 1056-1067.

HE, H., ZHOU, J., WU, Y., ZHANG, W. and XIE, X. 2008. Modelling the response of surface water quality to the urbanization in Xi' an, China. Journal of Environmental Management, no. 86, p. 731-749. http://dx.doi.org/10.1016/j.jenvman.2006.12.043

KANNEL, PR., LEE, S., LEE, YS., KANEL, SR. and PELLETIER, GJ. 2007. Application of automated QUAL2Kw for water quality modeling and management in the Bagmati River, Nepal. Ecological Modelling. no. 202, p. 503-517.

MARQUES, MN., COTRIM, MB. and PIRES, MAF. 2007. Avaliação do impacto da agricultura em áreas de proteção ambiental, pertencentes à bacia hidrográfica do rio Ribeira de Iguape, São Paulo. Quimica Nova, vol. 30, no. 5, p. 1171-1178.

OLIVEIRA, VM., SILVA, MSG., MEDEIROS, CB., JESUS, VE., PIO, EGM., PILLON, JF., LIMA, RP., BOMBO, AL., GODOY, BL., DETONI, AD., CONTER, P., BARONI JUNIOR., M., FRANCISCO, AR., BADDO, B., BROTA, GA.
FILHO, JLP., OLIVEIRA-NETO, AL., ALMEIDA, G., ROSSINI, AJ. and PELEGRINI, RT. 2008. Avaliações físicas, químicas e biológicas da microbacia do Córrego Modeneis em Limeira - SP. Engenharia Ambiental, vol. 5, no. 1, p. 86-96.

PARK, SS. and LEE, YS. 2002. A water quality modeling study of the Nakdong River, Korea. Ecological Modelling, vol. 152, p. 65-75.

RIGHETTO, AM. 1998. Hidrologia e Recursos Hidricos. São Paulo: Editora EDUSP.

ROSGEN, D. and SILVEY, HL. 1996. Applied river morphology. 2th ed. Colorado.

ROY, AH., ROSEMOND, AD., PAUL, MJ., LEIGH, DS. and WALLACE, JB. 2003. Stream macroinvertebrate response to catchment urbanization (Georgia, U.S.A.). Freshwater Biology, v. 48, p. 329-346. http:// dx.doi.org/10.1046/j.1365-2427.2003.00979.x

SARDINHA, DS., CONCEIÇÃO, FT., SOUZA, ADG., SILVEIRA, A., JULIO, M. and GONÇALVES, JCSI. 2008. Evaluation of the water quality and auto-purification from the Meio Stream, Leme (SP). Engenharia Sanitária e Ambiental, vol. 13, no. 3, p. 329-338.

United States Environmental Protection Agency USEPA. Available from: <www.epa.gov>. Acess in: 14 mar. 2007.

VANNOTE, RL., MINSHALL, GW., CUMMINS, KW., SEDELL, JR. and CUSHING, CE. 1980. The River Continuum Concept. Canadian Journal of Fisheries and Aquatic Science, vol. 1, no. 37, p. 130-137. 